\title{
Promotion of Blended Learning Usage in Science Teaching in Nigeria: Some Inhibiting Factors
}

\author{
A.O. Akinbobola, Ph.D \\ Department of Special Education and Curriculum Studies, Adeyemi College of Education, Ondo, Nigeria \\ E.N. Asagha \\ Department of Physics, Federal College of Education, Obudu, Nigeria
}

\begin{abstract}
E-learning is naturally suited to distance learning and flexible learning, but can also be used in conjunction with face-to-face teaching, in which case the term Blended Learning is commonly used. It is noted in Nigeria that technology-based tools are already beginning to change the conventional relationships or interaction among students themselves and between students and teachers by facilitating cooperative learning. The study revealed that students taught with blended learning performed significantly better than those taught with e-learning. However, the findings in this paper also indicate that, there are some obstacles to the successful integration of Blended Learning in teaching and learning of science. These include inadequate technical personnel, insecurity and poverty, poor network connectivity, inadequate avoidable computer equipment, epileptic power supply, lack of maintenance culture, and lack of competence, confidence and accessibility to technology-based tools by the students and teachers. Hence, this paper examines the strategies of integrating technology into classroom instruction across the school curriculum to optimize learning outcome, and argues for a technology-based students development that not only equips teachers and students with computer and other technological skills but in providing the kind of training that actively explores integrating technology (blended learning) into methods, courses and students learning activities.
\end{abstract}

Keywords: Blended Learning, Science, E-Learning, Technology.

\section{Introduction}

Blended learning is a type of education that combines face-to-face classroom strategies with computer-mediated activities to form an integrated instructional approach. The terms, web-enhanced instruction, mixed-mode instruction, hybrid, and technology-mediated instruction are often used interchangeably for blended learning. According to Margne (2003), blended learning is a formal education programme in which a student learns at least in part through online delivery of content and instruction with some element of student control over time, path, place and/or pace. The strategy creates a more integrated approach for both instructors and students.

The goal of a blended learning is to join the best aspects of both face-to-face and online instruction. Classroom time can be used to engage students in advanced interactive experiences. Meanwhile, the online portion of the course can provide students with multimedia-rich content at any time of day, anywhere the student has internet access such as computer laboratories, libraries and students' homes. This allows for an increase in scheduling flexibility for students. There are no rules in place to prescribe what the ideal blend might be. The term "blended" encompasses a broad continuum, and can include any integration of face-to-face and online instructional content. The blend of face-to-face and online activities will vary depending on the content, the needs of the students, and the preferences of the instructor.

E-learning is the delivery of a learning, training or education programme by electronic means. Elearning involves the use of a computer or electronic device (for example, a mobile phone) in some way to provide training, educational or learning material (Oblinger \& Hawkins, 2005). E-learning is naturally suited to distance learning and flexible learning, but can also be used in conjunction with face-to-face teaching, in which case the term blended learning is commonly used. E-learning and distance learning are not quite the same thing. The basic thing that distinguishes distance education is the physical separation of the student from the instructor and the classroom.

The concept of Open and Distance Learning (ODL) was proposed in Nigeria in the 1998 edition of National Policy on Education (FRN, 1998). Open learning is one of the most recent manifestations of a gradual trend towards the democratization of education. It is not a doubt that education and learning are traditionally 'closed' by various barriers ranging from entrance requirements, time constraints, financial demands, geographical locations, distances, social and cultural barriers to higher education (Udofot, 2007). Herein ODL will mitigate such hindrances to human capacity development.

According to Alaezi (2005), ODL refers to educational patterns, approaches and strategies that permit people to learn with no barriers in respect of time and space, age and previous educational qualifications - no entry qualification, no age limit, no regard to sex, race, tribe and state of origin. Jegede (2005) noted that ODL has developed from a modest and inconsequential beginning through correspondence courses to a full-fledged 
modern day technology-facilitated, flexible and learner-driven, self-directed learning. It involves learners who are often in locations remote from the institution and/or the instructional or tutorial facilitator. ODL provides an affordable, cost effective and flexible educational opportunity for all. This is why it must be the bridge of our educational system in the 21 st century. This, according to Jegede is because, if we continue to abandon the vast majority of our people outside of the sphere of educational opportunities, we make the country, and of course the world, not only less just, but also less secure.

ODL accommodates diverse learning styles, provides access to remote and normally inaccessible and under-represented groups. It meets the specific and special educational needs of a variety of learners. ODL can be used to reach a wider student population; to meet the needs of learners who are unable to attend on-campus lectures due to work, family, community responsibilities and women in Pudah or with child-rearing responsibilities; to meet the demand for life-long and life-wide education among the adult population especially in the provision of quality of life and in such areas as health care, and the provision of affordable education to the masses (Osuji, 2007). Since it also dwells and thrives on economics of scale, it is highly recommended as an avenue to learning in ways most appropriate, efficient and effective to the individual learners.

The Open University system is a 21st century development in Nigeria. According to Jegede (2004), the open university system in Nigeria is necessitated by many factors among them include; the ever-continuing growth in Africa's population, the attendant escalating demand for education at all levels, the difficulty of resourcing education through the traditional means of face-to-face classroom mode and the compelling need to provide education for all irrespective of environmental, social or cultural circumstances. It implies that Africa must find the appropriate and cost effective means to respond adequately to the huge unmet demand for education.

The rapid advancement of the computer and telecommunications technologies has also been identified by the same source as a factor in the proliferation of ODL since it allows access to materials by learners in different parts of the world anytime, anywhere and by the most appropriate means (Jegede, 2004). The orientation and information guide for students of the National Open University of Nigeria (NOUN) specifies the following modes of delivery: printed materials, audiotapes, videotapes, CD ROMS supplemented by radio and television broadcasts. The channels of delivery include courier and postal services, electronic transmission in voice, data, graphics, terrestrial and VSAT wireless communication systems, internet and face-to-face interactions at the network of study centres. Hence, National Open University of Nigeria (NOUN) make use of blended learning.

\section{Statement of the Problem}

Despite the advantages of blended learning that is been made use of by NOUN in order to meet wider students population, there are some students that are unable to attend face-to-face interactions at their respective NOUN study centres due to work, family, community responsibilities and women in Pudah or with child rearing responsibilities. They only make use of the e-learning which they access in their offices, libraries and homes through the internet facilities by making use of their computer accessories. The GSM revolution can also come to the aid of those who have no access to the computer as the internet can be assessed wherever one is, if the learners own a mobile phone with internet facilities. This implies that, there are two types of NOUN students namely students that are taught with blended learning and those that are taught without blended learning, that is, those that make use of e-learning without face-to-face interaction at their study centres. Hence, woud there be any difference in the performance of NOUN students taught with blended learning and those taught without blended learning?

\section{Research Hypothesis}

There is no significant difference in the academic performance of NOUN students taught with blended learning and those taught with e-learning.

\section{Research Method}

Ex-post facto design was adopted for the study. The population for the study comprised of all the 161 year one NOUN students that registered for physics courses at Akure study centre, Nigeria. These are: PHY 111: Elementary Mechanics, PHY 113: Heat and Properties of Matter, PHY 124: Geometric and Wave Optics and PHY 132: Electricity, Magnetism and Modern Physics.

Based on the fact that the population is few, all the students constituted the sample size of the study. The class attendance list was used to categorised students into blended learning and e-learning groups. Students that attended the face-to-face interaction were categorised as blended learning group while those students that did not attend were categorised as e-learning group. The instruments consisted of the NOUN standardised examination questions in PHY 111, PHY 113, PHY 124 and PHY 132 already validated and the reliability had been obtained by NOUN during 2012/2013 academic session. The data collected were analysed using t-test and 
the hypothesis was tested at .05 level of significance.

\section{Result}

\section{Hypothesis}

There is no significant difference in the academic performance of NOUN students taught with blended learning and those taught with e-learning.

The analysis is as shown in Table 1.

Table 1: t-test analysis of NOUN students' performance taught with blended learning and those with elearning.

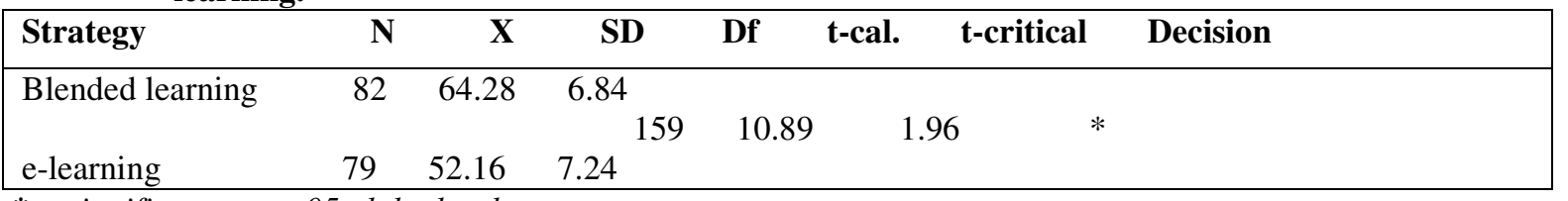

$*=$ significant at $p<.05$ alpha level

The analysis in Table 1 shows that, the calculated t-value of 10.89 is greater than the critical t-value of 1.96. Thus, the hypothesis which stated that, there is no significant difference in the academic performance of NOUN students taught with blended learning and those taught with e-learning is rejected. The table also shows that NOUN students taught with blended learning performed significantly better than those taught with elearning.

\section{Discussion}

The better performance of students in blended learning than e-learning might be due to the fact that, working together cooperatively enhances appropriate behaviour in organizing work, asking questions, encouraging social interaction, demonstrating self-management and facilitating better study habit and retention of knowledge. This is in line with the findings of Akinbobola (2011) that, working in small group enhances performance, promote learning and skills, and improve self-development through collaborative learning.

Also, blended learning enhances hands-on technology use. Hands-on technology use at school during face-to-face interaction allows students to develop confidence in their skills and a comfort level with the technology. When teachers are accustomed to using the equipment to boost their own productivity, they are more likely to see ways in which similar uses could support the projects they want their students to do. Blended learning also includes synchronous activities that involve the exchange of ideas and information with one or more participants during the same period of time. A face-to-face discussion is an example of synchronous communications. Synchronous activities occur with all participants joining in at once in virtual classroom or meeting.

Obstacles to the Successful Integration of Blended Learning in Teaching and learning of Science

Some of the barriers towards the use of blended learning in the teaching of science include:

(i) Poor Network Connectivity: The network connectivity is very poor and not reliable. The disconnection may come at any time without prior notices. The barriers include waiting for websites to open and failing to connect to the internet. The reason for the disconnection could be cabling problem, virus attack or web server maintenance problem. The situation may lead to frustration and discouragement on the part of the instructors and students.

(ii) Lack of Maintenance Culture and Technical Support: Technical problems include malfunctioning computers, students and teachers having to work on old computers and printers not printing. These barriers impeded the smooth delivery of the lesson or the natural flow of instructional activities. Due to lack of technical support and maintenance culture in study centres and schools, technical maintenance will not be carried out regularly, resulting in a higher risk of technical breakdowns.

(iii) Epileptic Power Supply: The effective use of Information Communication Technology (ICT) in blended learning in particular, demands the provision and availability of electricity supply. In Nigeria, unsteady power supply or none in some rural areas may have stood in the path of progress of the use of computer as an instructional tool in blended learning.

(iv) Inadequate Funding: Teacher education programmes require adequate funding. Funds are required for purchase of materials, tools and equipment, laboratory chemicals and reagents, as well as maintenance and replacement of these facilities. Despite the roles of education in the development of a nation, the yearly budget for education is very low (usually below 10\%) compare with other sectors in Nigeria budget (Efedi, 2008). Adequate attention has not been given to education in the area of funding in the country. Hence, inadequate funding may affect the procurement of ICT materials, tools and equipment 
for effective use in blended learning.

(v) Insecurity and Poverty: An average Nigerian is poor and lives below poverty line and as a result, some of the students cannot buy computer. Although, the cost of a computer nowadays is relatively less expensive, but the supply of computers to study centres is still very low. Insecurity is another problem to ICT utilization in Nigeria. Due to poverty and unemployment, ICT facilitating structures are prone to vandalisation by thieves. Hence, many people who can afford to buy computer are afraid of their own being stolen.

(vi) Lack of Competence, Confidence and Accessibility to Technology-Based Tools by the Students and Teachers: To live in an information age, there is the challenge of being familiar with and being able to operate ICT gadgets. Computer literacy is sine qua non to effective use of ICT. One can benefit from ICT only when one can use the computer to get to the internet. In contrary, very few teachers can operate the computer. The students who have idea of computer cannot effectively surf information with it. Under this prevailing condition, no reasonable application of ICT can take place in the school system. Hence, a lack of ICT skills is a serious obstacle to the integration of technologies into science education.

The main problem with the implementation of blended learning in science is the insufficient amount of in-service training programmes for teachers. These include lack of training in digital literacy, lack of pedagogical and didactic training in how to use ICT in the classroom, and lack of training concerning the use of technologies in specific areas of physics in particular, and science in general. Inappropriate teacher training is not helping teachers to use ICT in their classrooms and in preparing lessons because training programmes do not focus on teachers' pedagogical practices in relation to ICT but on the development of ICT skills. Inadequate or inappropriate training leads to teachers being neither sufficiently prepared nor sufficiently confident to carry out full integration of ICT in the classroom. Hence, teachers need to not only be computer literate but they also need to develop skills in integrating computer use into their teaching/learning programmes.

(vii) Lack of Access to Resources: Lack of access to resources, including home access is another obstacle that discourages teachers from integrating new technologies into education and particularly into science education. A student would have no access to ICT materials because most of these are shared with other students. Some of the barriers related to the accessibility of ICT include insufficient numbers of computers, insufficient peripherals, insufficient copies of software, insufficient simultaneous internet access, oldness or slowness of ICT systems, and scarcity of educational software in the school. The limitations on access to hardware and software resources influenced teachers and students' motivation to use ICT.

\section{Conclusion}

The national policy on education has identified that education is the most important instrument of change in any society and that any fundamental change in the intellectual and social outlook of any social has to be proceeded by an educational revolution. The advent of National Open University of Nigeria through the use of blended learning marks the beginning of this educational revolution already foreseen in the national policy on education. Hence, blended learning can serve as the bridge by providing answers to the needs of providing education for all irrespective of environmental, social or cultural circumstances. However, there are some obstacles to the successful integration of blended learning in teaching and learning of science. These include lack of competence, confidence and accessibility to technology-based tools by the students and teachers, inadequate funding, insecurity and poverty, poor network connectivity, lack of maintenance culture and technical support, and epileptic power supply.

\section{Strategies of Promoting Blended Learning Usage in Science Teaching in Nigeria}

In view of the implications of the findings from this study, the following recommendations are made:

The Power Holding Company of Nigeria (PHCN) should improve on its generation of electricity and the government should extend electricity to the rural communities where NOUN institutions are cited in particular and to all parts of the country in general. There should be adequate back-up systems such as standby generators, Uninterrupted Power Supply (UPS), stabilizers and diskettes to sustain the ICT system in the face of unstable electricity, disaster and other environmental hazards.

Computer education should be given its rightful place in our education system because of its importance in the development of the nation. It should be implemented at all levels of education. Computer education at all level will help to eradicate computer illiteracy so that, an average Nigerian will have the basic knowledge of computer and use it to solve problems and perform tasks.

ICT experts should be posted to NOUN study centres as a government policy. Digital libraries should be established in NOUN study centres by the government so that students can be connected to the internet. The 
stock of library should be updated regularly in order to provide current materials and information. Training programmes such as conferences, seminars and workshops should be organized often for staff of NOUN in all the study centres. The training programmes should deal with the new devices, modern technologies, and new pedagogical approaches. ICT resources including software and hardware, effective professional development, sufficient time, and technical support need to be provided for teachers. Policy makers, cognitive researchers and administrators, and technologists to work together effectively to harness the power in all the elements of ICT so that it can transform the productivity of educational systems, just as it is gradually but surely doing for business community and many other aspects of society.

Government, non-governmental organizations and multi-national companies should be encourage to be actively involved in the funding of teacher education. They should also provide grants in the area of procurement of ICT equipment and in-service training of teacher educators. Government should give sufficient grants to all levels of education based on the rising population. Also bursaries and scholarships should be given to students in order to procure computer and other ICT materials.

Science teachers should adopt the use of blended learning and emphasize on a variety of procedures for promoting insight, meaningfulness, organization of experience, discovery of interrelatedness among ideas and techniques, and the application of knowledge acquired in one situation to a variety of situations.

Hence, the strategies for integrating technology into classroom instruction across the school curriculum to optimize learning outcome, and argues for a technology-based students development that not only equips teachers with computer and other technological skills but in providing the kind of training that actively explores integrating technology (blended learning) into methods, courses and students learning activities should be emphasized.

\section{References}

Akinbobola, A.O. (2011). Teaching methods, study habits, school location and gender factors as determinants of retention ability of physics students in Nigeria senior secondary schools. IRCAB Journal of Arts and Education, 1(1), 152 - 158 .

Alaezi, O.A. (2005). National open university plan: Enhancing higher education in Nigeria through open and distance learning delivery systems. Lagos: NOUN.

Efedi, O.E. (2008). Women education: A vehicle for effective and efficient role performance in national development in Nigeria. Benin Journal of Gender Studies, 1(1), 66 - 75.

Federal Republic of Nigeria (FRN, 1998). National policy on education. Lagos: NERDC Press.

Jegede, O. (2004). Formulating viable national and regional information and communication technologies and open and distance learning policies. An invited keynote presentation of the sub-regional ministerial conference of integration of ICT's in education: Issues and challenges in Africa held at NICON-NOGA Hilton hotel, Abuja, 26th - 30th July.

Jegede, O. (2005). Inaugural speech at the induction workshop for NOUN staff facilitated by common wealth of learning, Victoria Island, Lagos, 17th - 21st January.

Margne, M. (2003). The hybrid online model: Good practice. Education Quarterly, 4, 18-23.

Oblinger, D.G. \& Hawkins, B.L. (2005). The myth about e-learning. Education Review, 6, 14-15

Osuji, U.S.A. (2007). Open and distance learning: The bridge in Nigerian educational system in the 21st century. In E.N. Etuk, I.M. Udofot, \& A.E. Udosen (Eds.), Education in Nigeria in the 21st century: Focus and imperative. Uyo: Abaam Publishing Co.

Udofot, I. (2007). Information and communication technology in distance language learning: Implications for open university education in Nigeria. In E.N. Etuk, Udofot, \& A.E. Udosen (Eds.), Education in Nigeria in the 21st century: Focus and imperative. Uyo: Abaam Publishing Co. 
The IISTE is a pioneer in the Open-Access hosting service and academic event management. The aim of the firm is Accelerating Global Knowledge Sharing.

More information about the firm can be found on the homepage:

http://www.iiste.org

\section{CALL FOR JOURNAL PAPERS}

There are more than 30 peer-reviewed academic journals hosted under the hosting platform.

Prospective authors of journals can find the submission instruction on the following page: http://www.iiste.org/journals/ All the journals articles are available online to the readers all over the world without financial, legal, or technical barriers other than those inseparable from gaining access to the internet itself. Paper version of the journals is also available upon request of readers and authors.

\section{MORE RESOURCES}

Book publication information: http://www.iiste.org/book/

Academic conference: http://www.iiste.org/conference/upcoming-conferences-call-for-paper/

\section{IISTE Knowledge Sharing Partners}

EBSCO, Index Copernicus, Ulrich's Periodicals Directory, JournalTOCS, PKP Open Archives Harvester, Bielefeld Academic Search Engine, Elektronische Zeitschriftenbibliothek EZB, Open J-Gate, OCLC WorldCat, Universe Digtial Library, NewJour, Google Scholar

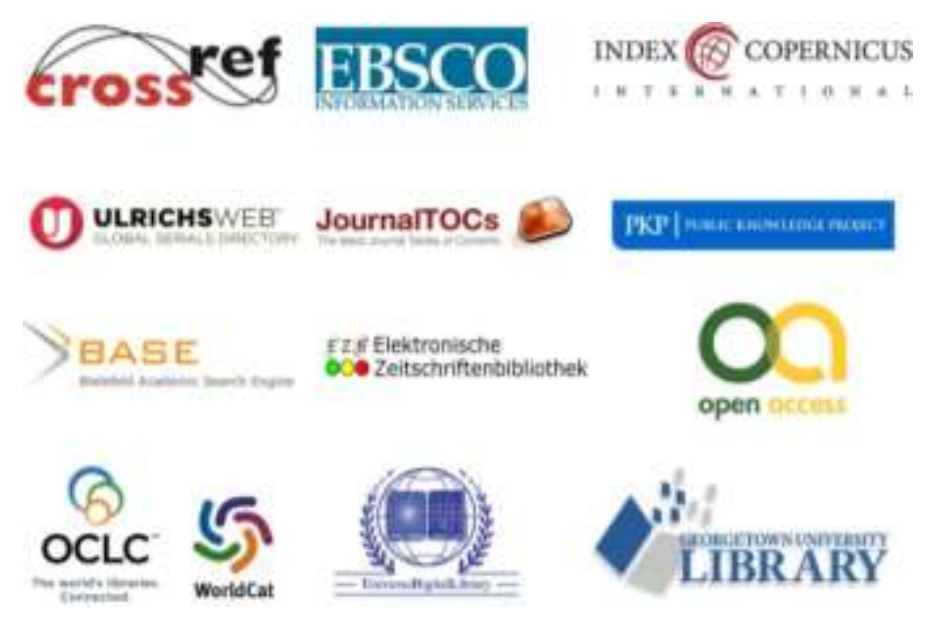

